\title{
Soil Layer Properties of a Profile Developed on the Past Depositional Series on Merbabu Volcano Central Java Indonesia
}

\author{
Mohammad Nurcholis $^{1 *}$, Susila Herlambang ${ }^{1}$, Sri Aminah Suwartikaningsih ${ }^{1}$, \\ Dian Fiantis ${ }^{2}$ and Dwi Fitri Yudiantoro ${ }^{3}$ \\ ${ }^{1}$ Department of Soil Science, Universitas Pembangunan Nasional Veteran Yogyakarta, Yogyakarta, 55283, \\ Indonesia. ${ }^{2}$ Department of Soil Science, Andalas University, Padang 25163, Indonesia \\ ${ }^{3}$ Department of Geological Engineering, Universitas Pembangunan Nasional Veteran Yogyakarta, Yogyakarta, \\ 55283, Indonesia,*e-mail: nurcholis@upnyk.ac.id
}

Received October 26, 2018; Revised December 12, 2018; Accepted 14 April 2019

\begin{abstract}
A wide and deep soil profile (around $1200 \mathrm{~cm}$ ) was observed at Ketep Park, West Slope of Merbabu Volcano, Central Java, Indonesia to identify the soil morphological, physical, chemical and mineralogical properties. The results showed that several soil development processes occurred in each volcanic deposit with different characteristics. Most soil layers met some of andic soil properties criteria such as bulk density $<0.9 \mathrm{~g} \mathrm{~cm}^{-3}$, P-retention $>85 \%$, and $\left(\mathrm{Al}_{\mathrm{o}}+1 / 2 \mathrm{Fe}_{\mathrm{o}}\right)>2.0 \%$. A thin melanic material showing black color layer was found at the lower layer of the soil profile, i.e. in depth of 726 to $798 \mathrm{~cm}$. The predominant material in most soil layers is allophane. Minerals in the sand fraction were dominated by labradorite and augite, with some layers were dominated by hypersthene and green hornblende.
\end{abstract}

Keywords: Layers, melanic material, volcanic materials

\begin{abstract}
ABSTRAK
Profil tanah yang luas dan dalam (sekitar $1200 \mathrm{~cm}$ ) diamati di Ketep Park lereng barat gunung Merbabu Jawa Tengah, Indonesia untuk mengidentifikasi sifat morfologi, fisika, kimia dan mineralogi tanah. Hasil penelitian menunjukkan bahwa beberapa proses pengembangan tanah terjadi pada setiap endapan vulkanik dengan karakteristik yang berbeda. Sebagian besar lapisan tanah memenuhi beberapa kriteria sifat tanah andik seperti berat volume $<0,9$ $\mathrm{g} \mathrm{cm}^{-3}$, retensi $\mathrm{P}>85 \%$, dan $\left(\mathrm{Al}_{0}+1 / 2 \mathrm{Fe}_{\mathrm{o}}\right)>2,0 \%$. Bahan melanik tipis yang menunjukkan lapisan warna hitam ditemukan di bagian bawah profil tanah, yaitu pada kedalaman 726 hingga $798 \mathrm{~cm}$. Material yang dominan di sebagian besar lapisan tanah adalah alofan. Mineral dalam fraksi pasir didominasi oleh labradorit dan augit, dengan beberapa lapisan didominasi oleh hipersten dan hornblende hijau.
\end{abstract}

Kata kunci: bahan volkanik, bahan melanik, lapisan tanah

\section{INTRODUCTION}

Soils derived from volcanic ash materials are regionally important in Indonesia (Supriyo 1992; Utami 2000; Ugolini and Dahlgren 2002; Fiantis et al. 2011). From time to time, new volcanic materials cover the soil surface. The effect of new material deposition on the properties of top soils to a great extent depends on the existing soil materials that receive sediments, and the origin of the transported

J Trop Soils, Vol. 24, No. 2, 2019: 53-63

ISSN 0852-257X; E-ISSN 2086-6682 materials (Krasilnikov 2007). The susceptibility of the common primary minerals to weathering processes is related to the discontinuous and continuous series identified in magmatic crystallization (Wilson 2004). Soils developed in an active volcanic environment receive parent material deposition periodically in accordance with the ongoing volcanic activity. The addition of new materials can change the properties of the soils that have been formed or developed previously. The development of volcanic soils has been periodically reported in previous studies (Shoji and Takahashi 2002; Ugolini and Dahlgren 2002; Zehetner 2003; Neall 2009; Fiantis et al. 2011). 
Unlike volcanic soils originated from the Merapi volcano, volcanic soils of Mt. Merbabu have not been studied previously. Merbabu Volcano is one of the andesitic volcanoes in Java resulted from tectonic activities in the Sunda arc. Merbabu Volcano is a stratovolcano of a series of Ungaran, Telomoyo, Merbabu and Merapi Volcanoes that occupies from north to south (Murwanto et al. 2004; Gomez et al. 2010). Soil forming processes in volcanic region are interrupted by depositional volcanic materials, after volcanic eruption. These processes can be observed in Merbabu volcanic soils. Alternate deposition of new volcanic materials buried existing soils, and new soil forming processes were started. The alternating processes of soil formation and material deposition generally occur in the volcanic area, especially in the body of the volcano. In this case, the rate of soil forming process and volcanic material deposition may control the development of the soil.

Certain rocks, which are mainly volcanic origin, produce high quantities of aluminum and silica due to weathering process. Those two constituents are able to form short-range aluminum silicate, which is amorphous, called allophane (Zhao 1997). Allophane is formed rapidly upon weathering of volcanic glass. Volcanic materials, especially ashes, generally contain large amount of volcanic glass. Allophane formation is determined by four main factors, i.e. availability of $\mathrm{Al}, \mathrm{pH}$, complexion of $\mathrm{Al}$ by organic matter (Takahashi and Dahlgren 2016), and availability of silica. The study on volcanic activity of Merbabu Volcano is not that intensive compared to the Merapi Volcano that is located in south. This is because currently the Merbabu Volcano is not an active volcano. The present study was aimed to characterize the soil layers developed from the series of the depositional materials from Merbabu volcano.

\section{MATERIALS AND METHODS}

\section{Study Site}

A wide and deep soil profile $(1200 \mathrm{~cm})$ with GPS coordinate $7.4946^{\circ} \mathrm{S}, 110.3813^{\circ} \mathrm{E}$ was exposed after a construction work of a Ketep Park at west slope of Merbabu Volcano, Central Java. The Ketep Park area is surrounded by agricultural fields that are commonly cultivated with vegetable crops.

\section{Soil Description}

Description of the soil profile was done according to Jahn et al. (2006) to identify the layering process of the volcanic activities in the past, and also the environmental condition that might occur between two sequential layers. The depth of every soil layer was measured and the type of layering was determined. Soil morphological characteristics were determined in the field and soil samples were collected from the morphologic layers. The soil physical properties including structure and consistency were also identified in the field. The $\mathrm{pH}(\mathrm{NaF} 1 \mathrm{M}, 1: 50)$ was measured at field to guarantee that there was no change in the amorphous materials according to Kleber (2004). Undisturbed and disturbed soil samples of each layer were collected to determine the physical, chemical and mineralogical properties of the soil.

\section{Soil Analysis}

The soil samples were air dried, sieved $(<2 \mathrm{~mm})$ and stored in plastic container prior to analysis. Water content at 1.5 MPa was determined on ground air-dried sample. Soil $\mathrm{pH}$ was measured using extracts of $1: 1 \mathrm{H}_{2} \mathrm{O}$ and $1: 1 \mathrm{KCl}$. Soil texture was determined by mechanical analysis after oxidizing the organic materials, as chelating agents, using hydrogen peroxide (Day 1965). Particle density of the soil was determined using picnometer. Non crystalline materials were identified by selective dissolution method by using acid ammonium oxalate and Na-pyrophosphate (McKeague 1967), the extracted elements of $\mathrm{Fe}, \mathrm{Al}$ and $\mathrm{Si}$ were determined by Atomic Absorption Spectrophotometer (AAS). $\mathrm{The} \mathrm{Fe}, \mathrm{Al}$, and Si that were reacted with organic constituents were analyzed using Na pyrophosphate as Fep, Alp, and Sip, respectively. Phosphate retention was determined according to Haamazaki and Paningbatan $\operatorname{Jr}(1988)$. A polarizing microscope was used to study the fine sand fraction $(50-500$ $\mu \mathrm{m})$. The sand particles were mounted with Canada balsam on a glass slide and covered with a cover glass. The minerals were counted according to the line method. Melanic materials were identified according to Honna et al. (1988).

\section{RESULTS AND DISCUSSION}

\section{Geological Setting of Merbabu Volcano}

The height of Mount Merbabu is $3.145 \mathrm{~m}$ above sea level and Mount Merbabu belongs to the stratovolcano group of the Volcanoes of Ungaran, Telomoyo, and Merapi. The volcano is now in a dormant state, but geographically the Merbabu Volcano is located in the north of Merapi Volcano, which is among the most active volcanoes in the world and still active today (Figure 1). Regionally, this mountain is part of a series of volcanoes in the ring of fire that pass in the territory of Indonesia, 


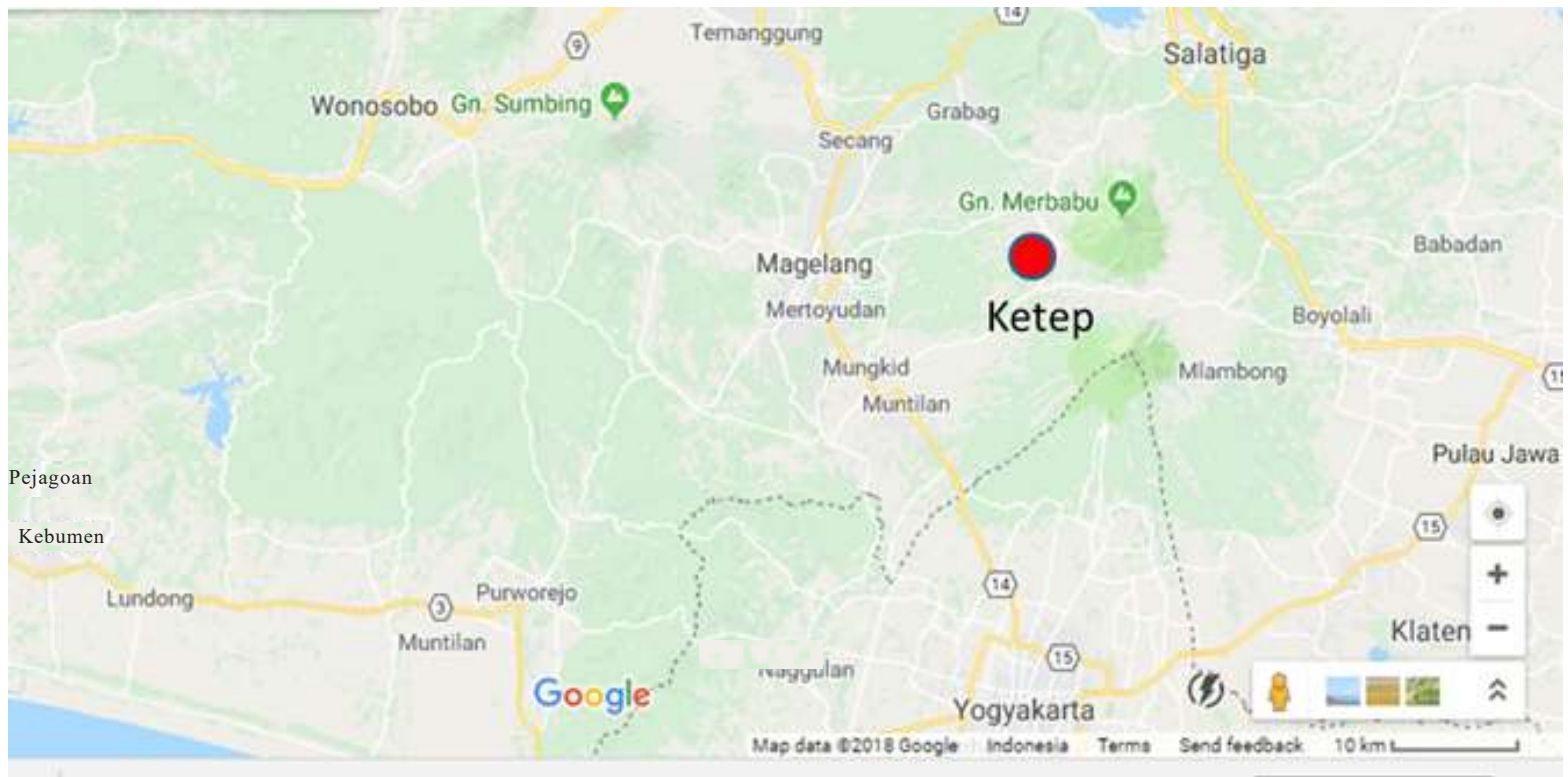

Figure 1. Regional map of Central Java, the research area is marked with the red dot.

including Islands of Sumatra, Java, Nusa Tenggara, and Sulawesi. This volcano is included in the quarterly period, and geomorphologically located in the middle of depression zone in Central Java region (Van Bemmelen 1949). Information about volcanic activities of Mount Merbabu was not recorded well after the last eruption in the year 1600-1779. It is suspected that Merbabu Volcano has erupted predominantly in the form of efusif as evidenced by the presence of lava. While in certain periods Merbabu Volcano erupted predominantly in the form of explosive as indicated by a thick layer of pyroclastic material (Mulyaningsih et al. 2016). The pyroclastic material, which covers the body of the Merbabu Volcano and its surrounding region, is the parent material of the formed soil. The relationship between stratovolcano, pyroclastic material, soil parent materials, and the development of soil in each layer is of interest of this study. Particular study on the geological aspects of Merbabu Volcano has not been done intensively, since the status of this volcano is inactive. However, the use of volcanic soil of Merbabu Volcano is very intensive especially for horticulture and floriculture cultivations. Therefore, the pedological, physical, chemical, and mineralogical aspects of the development of the soil in Merbabu Volcano become very important.

\section{Soil Morphological Properties}

The soil profile showed a series of layering, which is not in the same direction as the slope of Merbabu Volcano. This feature was resulted from volcanic activities in the past, especially Merbabu eruptions, which resulted in thick stratovolcano (van
Padang 1951). There are twenty-one layers within $1200 \mathrm{~cm}$ depth of the soil profile (Table 1). The colors of most layers are in the range of yellowish brown to very pale brown, but there are two layers (i.e. 16th and 17th layers, at the depth of 726 to $798 \mathrm{~cm}$ ) with brownish black colors, and both layers showed a specific feature, which was identified as melanic material (Figure 2). The presence of melanic material in soil indicates that there is abundance of Type A humic acid in the organic matter and it gives the dark color of soil (Takahashi and Shoji 2002). The presence of melanic materials in these layers shows that during a certain period a long pause between volcanic activities occurred. That period was sufficient for the weathering of volcanic materials and vegetation growth. In this period, humus resulted from the decomposition of the remaining vegetation interacts with amorphous materials forming melanic materials which is characterized by the black color. Melanic epipedon might be also developed from charcoal as a result of heating organic matter with very low oxygen content by a thick pile of hot volcanic materials (Takahashi and Dahlgren 2016).

Residual plant roots were observed in the studied soil profile from the surface layer to the dark color layer (Table 1). Only a few numbers of roots was found and the size of the roots was fine. It was suggested that the roots were originated from small type vegetation, such as thimoty grass (Phleum pratense). It was also thought that there were serial vegetation successions occured in the past after depositions of volcanic materials, as shown by several soil layers containing residual roots. According to the appearance of the soil layers, 


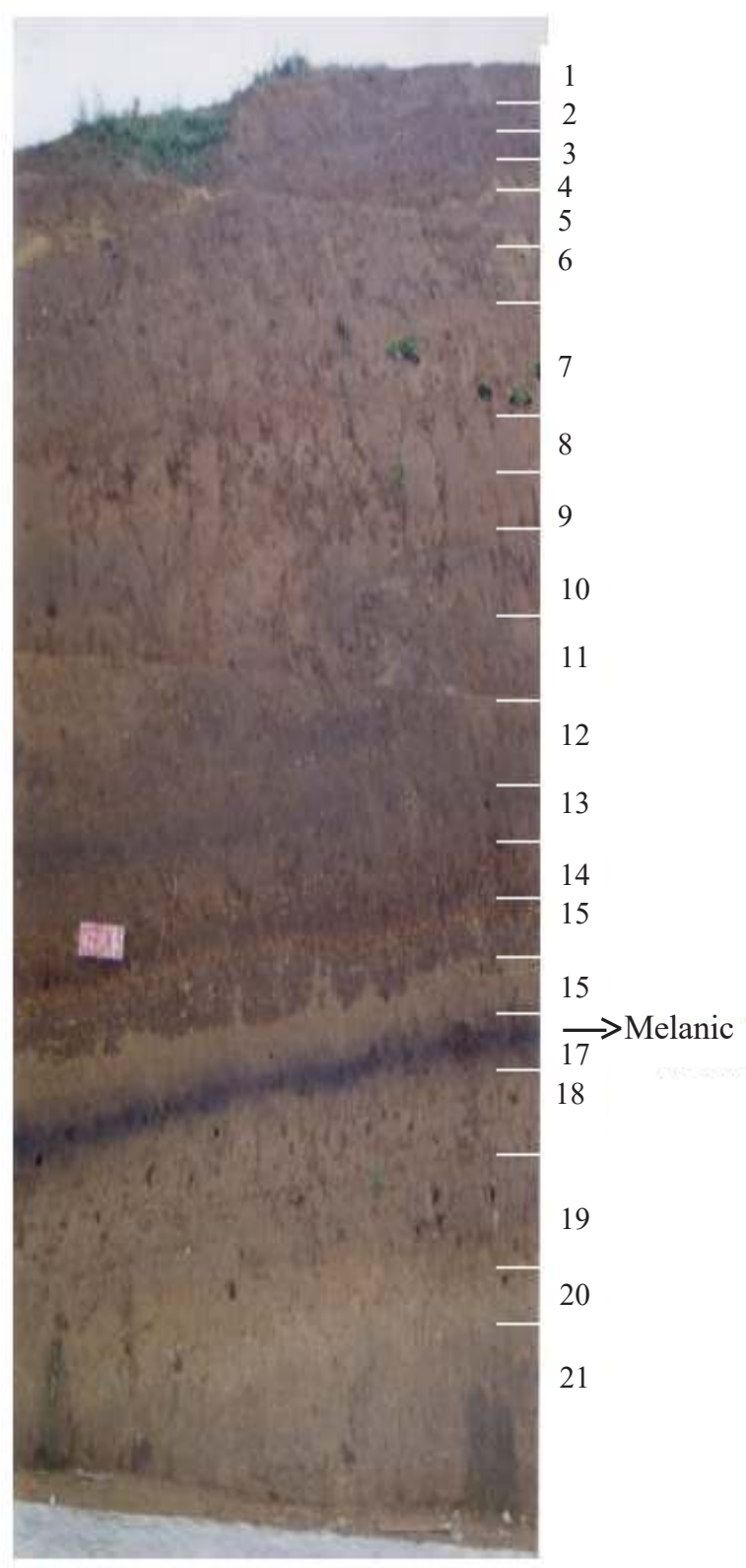

Figure 2. The soil profile of Ketep Park area, Central Java Province.

numerous vegetation were able to grow on the surface of a new depositional layer. When the following materials with high temperature came to the surface, the vegetation was buried and then it was died and oxidized completely. A special feature was observed in the layers 12 to 17 , i.e. at depth 557 to $798 \mathrm{~cm}$, which showed a plenty root content. It is thought that these roots in the soil layers were might be preserved by following thick and cool material depositions from Merbabu volcanic activity. These thick and cool materials might cause a lack of oxygen, so that it did not support the decomposition of organic matter, including plant roots. On the other hand, the other layers that did not show the presence of plant roots might be resulted from the
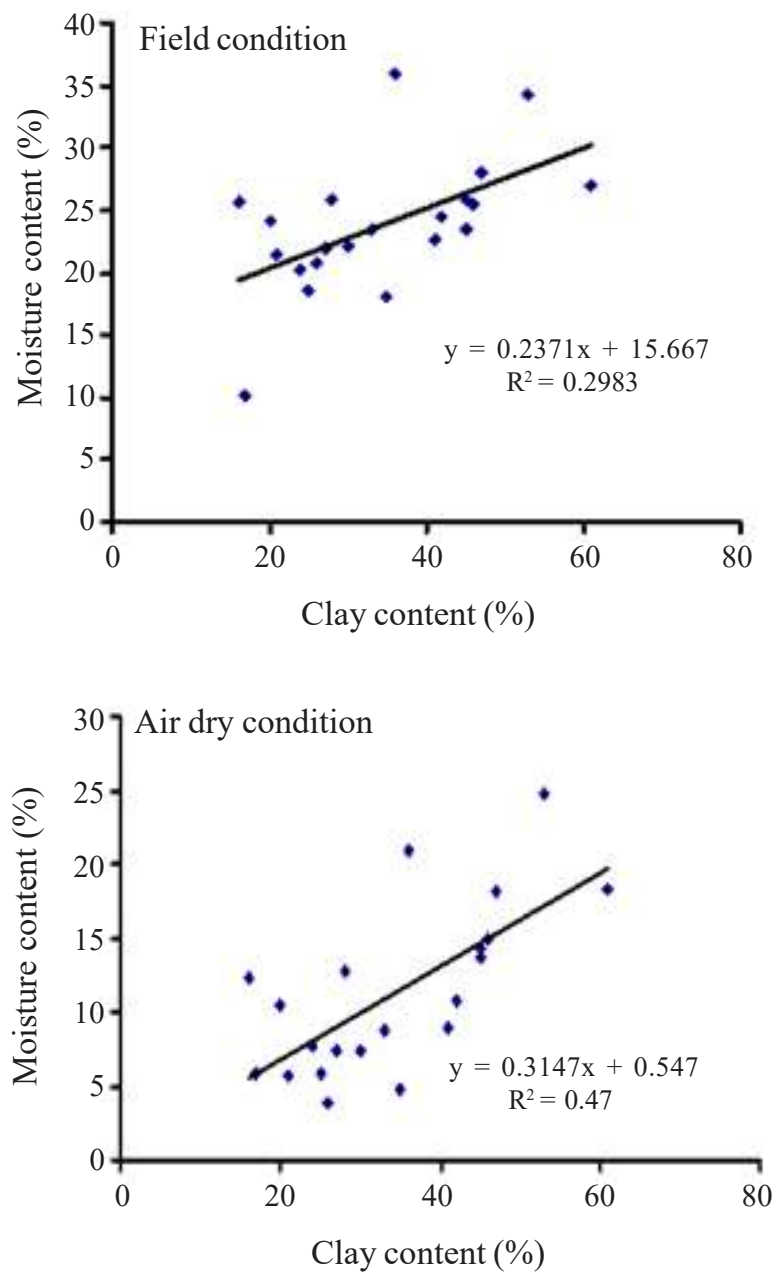

Figure 3. Relationship between clay content and soil water content at field and air dry conditions.

decomposition of organic matter, including the plant roots in the past period.

Egashira et al. (1997) reported that black-color soils under grass vegetation are distributed in the mountainous area surrounding Cochambamba basin in Bolivia. The black-color soil was formed due to the local farmers usually burned the grass in the past. According to the size of vegetation roots, there are some possibility that can be predicted. Firstly, the time interval between depositional processes was short, so that the vegetation succession had not reached higher plants, as forest might increase the carbon exponentially (Hunziker et al. 2019). Secondly, the climate condition at that period did not promote growing higher plants.

\section{Soil Physical Properties}

Table 2 shows the soil physical properties of every soil layer of the profile. Soil textural classes of the profile showed a pattern of sandy loam, loamy 
Table 1. Morphological properties of the soil.

\begin{tabular}{|c|c|c|c|c|c|c|}
\hline \multirow{2}{*}{ No } & \multirow{2}{*}{$\begin{array}{c}\text { Depth } \\
(\mathrm{cm})\end{array}$} & \multicolumn{2}{|c|}{ Soil Color } & \multirow{2}{*}{ Texture } & \multicolumn{2}{|c|}{ Root } \\
\hline & & Code & Color & & Content & Size \\
\hline 1 & $0-21$ & 10YR5/4 & Yellowish brown & sa. Loam & Few & Fine \\
\hline 2 & $21-96$ & $10 \mathrm{YR} 5 / 8$ & Yellowish brown & sa. Loam & many & Fine \\
\hline 3 & $96-138$ & 10YR6/8 & Brownish yellow & sa. Loam & - & - \\
\hline 4 & $138-183$ & 10YR6/6 & Brownish yellow & c. loam & Few & Fine \\
\hline 5 & $183-229$ & $10 Y R 5 / 4$ & Yellowish brown & sa. c. Loam & Few & Fine \\
\hline 6 & $229-295$ & $10 Y R 7 / 3$ & Very pale brown & sa. c. Loam & - & - \\
\hline 7 & $295-359$ & $10 Y R 7 / 4$ & Very pale brown & sa. c. Loam & - & - \\
\hline 8 & $359-441$ & $10 Y R 7 / 3$ & Very pale brown & sa. C. Loam & - & - \\
\hline 9 & $441-468$ & $10 Y R 5 / 4$ & Yellowish brown & sa. C. Loam & - & - \\
\hline 10 & $468-548$ & $10 \mathrm{YR} 6 / 3$ & Brown & sa. C. Loam & - & - \\
\hline 11 & $548-557$ & $10 Y R 7 / 4$ & Very pale brown & sa. Loam & - & - \\
\hline 12 & $557-605$ & $10 Y R 5 / 4$ & Yellowish brown & sa. Loam & Few & Fine \\
\hline 13 & $605-652$ & $10 \mathrm{YR} 4 / 4$ & Yellowish brown & sa. C. Loam & Few & Fine \\
\hline 14 & $652-714$ & 10YR5/4 & Yellowish brown & sa. Loam & Few & Fine \\
\hline 15 & $714-726$ & 10YR5/8 & Yellowish brown & sa. Loam & Common & Fine \\
\hline 16 & $726-755$ & 5YR3/1 & Brownish black & c. loam & Common & Fine \\
\hline 17 & $755-798$ & $10 \mathrm{YR} 3 / 1$ & Brownish black & Loam & Common & Fine \\
\hline 18 & $798-912$ & $10 \mathrm{YR} 5 / 4$ & Yellowish brown & sa. C. Loam & - & - \\
\hline 19 & $912-1005$ & $10 Y R 5 / 4$ & Yellowish brown & sa. C. Loam & - & - \\
\hline 20 & $1005-1063$ & $10 Y R 4 / 4$ & Yellowish brown & Clay & - & - \\
\hline 21 & $1063-1094$ & $10 Y R 7 / 8$ & Yellow & sa. Loam & - & - \\
\hline
\end{tabular}

clay, sandy clay loam, sandy loam and clay. The large variation of soil particle distribution showed a variation in sedimentation of soil parent materials resulting from series of Merbabu volcanic eruptions. According to the morphological properties (Table 1) it is also thought that there were variations in environmental condition that influenced the soil genesis processes. Dynamic of material deposition and soil genesis in the volcanic environment is also recorded in the inter-Andean Valley of Northern Equador, resulting in the Paleosols formation (Zehetner et al. 2003).

In the present study, all the soil samples from each layer have low bulk density, i.e. $<1.00 \mathrm{~g} \mathrm{~cm}^{-3}$. The greater part of mineral fractions of ordinary soils consists of quartz, feldspars, and clay; the bulk density of mineral soil free organic matter is generally about $2.65 \mathrm{~g} \mathrm{~cm}^{-3}$. The bulk density of soil is lowered by the presence of organic matter, and raised by the presence of oxides of iron such as magnetite, hematite, and limonite, and to a smaller degree by the presence of ferromagnesian and micas. It is assumed that the density of soil is an additive function of the densities of its constituents. Most soils have bulk density lower than $0.90 \mathrm{~g} \mathrm{~cm}^{-3}$, which are included in the common Andisols (Nanzyo 2002; Rasmussen et al. 2007). The data shows that the clay content is relatively high and accompanied by iron and aluminum as oxides on the several layers (Table 2 and 3). However, the role of amorphous materials that provide pores or cavities has resulted in these materials have bulk density less than $1.00 \mathrm{~g}$ $\mathrm{cm}^{-3}$. This value also suggested that the soil clods are built up from the amorphous materials and have numerous pores. This "lightness" of the soil has been referred to a "fluffy" character, which is expressed as a friable consistency.

Relationships between the clay content and moisture content of soil samples in field (a) and air dry (b) conditions are presented in Figure 3. The $\mathrm{R}^{2}$ value of the regression between the clay content and the moisture content in the air dry soil samples was higher than that in the field samples, in the air dry condition the value of $\mathrm{R}^{2}=0.470$, and when the moisture content of field condition the $\mathrm{R}^{2}=0.2983$ (Figure 3). This result indicates that the role of the materials that can hold water in the moist condition is not only the clay material. Moisture content in the field conditions are also affected by other constituents. The properties of soil containing amorphous material can store the moisture at moderate pressure, so that the soil moisture content in field conditions can be augmented by the presence of amorphous materials. Water can be hold in the pores of amorphous materials, such as allophane (Ugolini and Dahlgren 2002), which is resulted from 
Table 2. The soil physical properties.

\begin{tabular}{|c|c|c|c|c|c|c|c|c|c|}
\hline \multirow{2}{*}{ No } & \multirow{2}{*}{$\begin{array}{l}\text { Depth } \\
\text { (cm) }\end{array}$} & \multirow{2}{*}{$\begin{array}{l}\begin{array}{l}\text { Parrticle } \\
(\%)\end{array} \\
\text { Sand }\end{array}$} & \multicolumn{2}{|c|}{ distribution } & \multirow[t]{2}{*}{$\begin{array}{l}\text { Bulk } \\
\text { Density }\end{array}$} & \multirow{2}{*}{$\begin{array}{l}\text { Particle } \\
\text { Density } \\
\text { g.cm }\end{array}$} & \multirow{2}{*}{$\begin{array}{c}\text { Porosity } \\
\text { (\%) }\end{array}$} & \multicolumn{2}{|c|}{ Water content $(\%)$} \\
\hline & & & Silt & Clay & & & & Field & Air dry \\
\hline 1 & $0-21$ & 57 & 8 & 35 & 0.89 & 2.10 & 57.61 & 18.06 & 4.72 \\
\hline 2 & $21-96$ & 55 & 24 & 21 & 0.98 & 2.17 & 54.84 & 21.47 & 5.66 \\
\hline 3 & $96-138$ & 67 & 7 & 26 & 0.96 & 2.38 & 59.66 & 20.82 & 3.80 \\
\hline 4 & $138-183$ & 37 & 35 & 28 & 0.79 & 1.56 & 49.36 & 25.75 & 12.82 \\
\hline 5 & $183-229$ & 52 & 23 & 25 & 0.90 & 2.16 & 56.31 & 18.58 & 5.84 \\
\hline 6 & $229-295$ & 39 & 19 & 42 & 0.76 & 2.19 & 65.29 & 24.43 & 10.70 \\
\hline 7 & $295-359$ & 25 & 29 & 46 & 0.91 & 1.86 & 51.07 & 25.41 & 14.94 \\
\hline 8 & $359-441$ & 21 & 34 & 45 & 0.82 & 1.55 & 47.09 & 23.47 & 14.30 \\
\hline 9 & $441-468$ & 44 & 15 & 41 & 0.92 & 1.79 & 48.60 & 22.60 & 8.90 \\
\hline 10 & $468-548$ & 58 & 15 & 27 & 0.83 & 2.54 & 67.32 & 21.93 & 7.32 \\
\hline 11 & $548-557$ & 42 & 28 & 30 & 0.77 & 1.39 & 44.60 & 22.13 & 7.32 \\
\hline 12 & $557-605$ & 56 & 20 & 24 & 0.77 & 2.24 & 65.62 & 20.31 & 7.74 \\
\hline 13 & $605-652$ & 48 & 19 & 33 & 0.75 & 1.79 & 58.10 & 23.52 & 8.84 \\
\hline 14 & $652-714$ & 73 & 10 & 17 & 0.92 & 1.95 & 52.82 & 10.06 & 5.80 \\
\hline 15 & $714-726$ & 54 & 26 & 20 & 0.79 & 1.92 & 58.85 & 24.17 & 10.50 \\
\hline 16 & $726-755$ & 15 & 32 & 53 & 0.88 & 1.44 & 38.89 & 34.31 & 24.82 \\
\hline 17 & $755-798$ & 27 & 37 & 36 & 0.78 & 1.58 & 50.63 & 35.89 & 20.86 \\
\hline 18 & $798-912$ & 40 & 13 & 47 & 0.95 & 1.42 & 33.09 & 28.04 & 18.08 \\
\hline 19 & $912-1005$ & 41 & 14 & 45 & 0.89 & 1.82 & 51.09 & 25.77 & 13.76 \\
\hline 20 & $1005-1063$ & 30 & 9 & 61 & 0.84 & 1.33 & 36.84 & 26.94 & 18.38 \\
\hline 21 & $1063-1094$ & 64 & 20 & 16 & 0.94 & 1.34 & 29.85 & 25.62 & 12.36 \\
\hline
\end{tabular}

the reassemble of weathering product of volcanic ashes from Merbabu volcano's eruptions in the past. This result is also supported by the $\mathrm{R}^{2}$ value of the relationship between soil porosity and the moisture content. The $\mathrm{R}^{2}$ value in the air dry condition $\left(\mathrm{R}^{2}=\right.$ 0.3646 ) was higher than that in the field condition, i.e. $\mathrm{R}^{2}=0.1817$ (Figure 4). Amorphous materials that have an irregular arrangement of aluminum and silica result in variable of pore sizes and forms. The greater porosity of the soil in terms of soil physics should be easier to drain water. The results indicate that besides soil porosity, the presence of amorphous materials has improved the soil ability to hold water, and it may give potential for mass movement (Chavarriaga et al. 2017). The low soil bulk density also provide support for the soil properties that may hold water (Table 2).

Thixotropic property was observed at the layers around the dark color layers (layer 16 and 17). This property is a general sign of the soil that is dominated by amorphous materials. When a soil clod in humid condition is placed between fingers and thumb of our hand and given a pressure, this clod then "like" give a reaction to defense the presence of soil clod. After following pressure is added, the clod is then broken vastly, and the soil clod becomes fluid (smeary), while water is expelled. This feature was a result of the forced water in the pores of amorphous materials. The amorphous materials are characterized by having abundant pores that formed in the alumino-silicate arrangement. These pores are available for water to enter the pores, and the water is fixed tightly so that it builds a system that firm enough (Díaz-Rodríguez and Santamarina 1999). The abundance of moisture in volcanic soils has a potency for supporting plant growth, i.e. favorable for root elongation and high tractability (Shoji and Takahashi 2002). Amorphous materials derived from weathering products of volcanic materials usually form allophane.

\section{Soil Chemical Properties}

Selected soil chemical properties were shown in Table 3. Soil $\mathrm{pH}\left(\mathrm{H}_{2} \mathrm{O}\right)$ in all soil layers showed a little variation with the range between 5.7 and 6.4. Organic matter content in all soil layers was varied. The organic $\mathrm{C}$ content was not regularly distributed on the soil surface until the layer $4(0-183 \mathrm{~cm})$, then regularly increased from layer 5 until 13 (183-652 $\mathrm{cm})$. The decrease of the organic $\mathrm{C}$ content was observed regularly from the layer 16 until the last layer of the profile. The pattern of the organic carbon content at depth of 726-1094 cm might be related to 

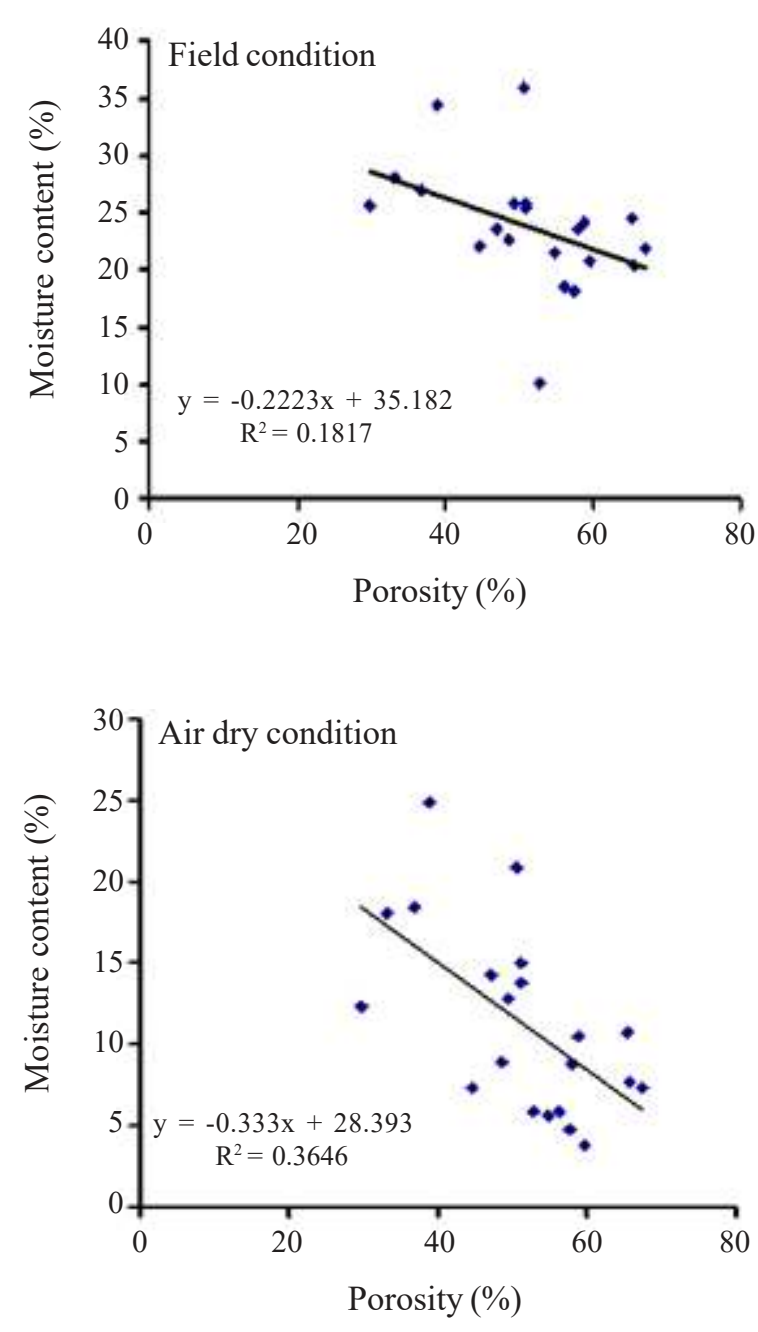

Figure 4. Relationship between soil porosity and soil moisture content at the field and air dry conditions.

the root content at the depth of $557-798 \mathrm{~cm}$. It also related to the gradational change of the soil colors from dark brown to yellow (Table 1). The highest content of organic matter was shown in the layer 16, i.e. at depth of 726 to $755 \mathrm{~cm}$. The high soil organic $\mathrm{C}$ content may be attributed to great net primary production and enhanced physico- chemical protection of $\mathrm{C}$ in the fine soil matrix. The soil organic $\mathrm{C}$ content and the black color of soil humus have relationship with the vegetation that grow along soil layers up to the top soil layer (Nanzyo 2002).

The layer that contained the highest soil organic $\mathrm{C}$ showed a thixotropic property. Reaction between organic matter and allophanic materials resulted in materials with porous structures. These materials may allow water, which comes from surrounding environment, to enter the inner spaces of the materials. The shape of the soil structure is able to withstand the small pressure from the surrounding,

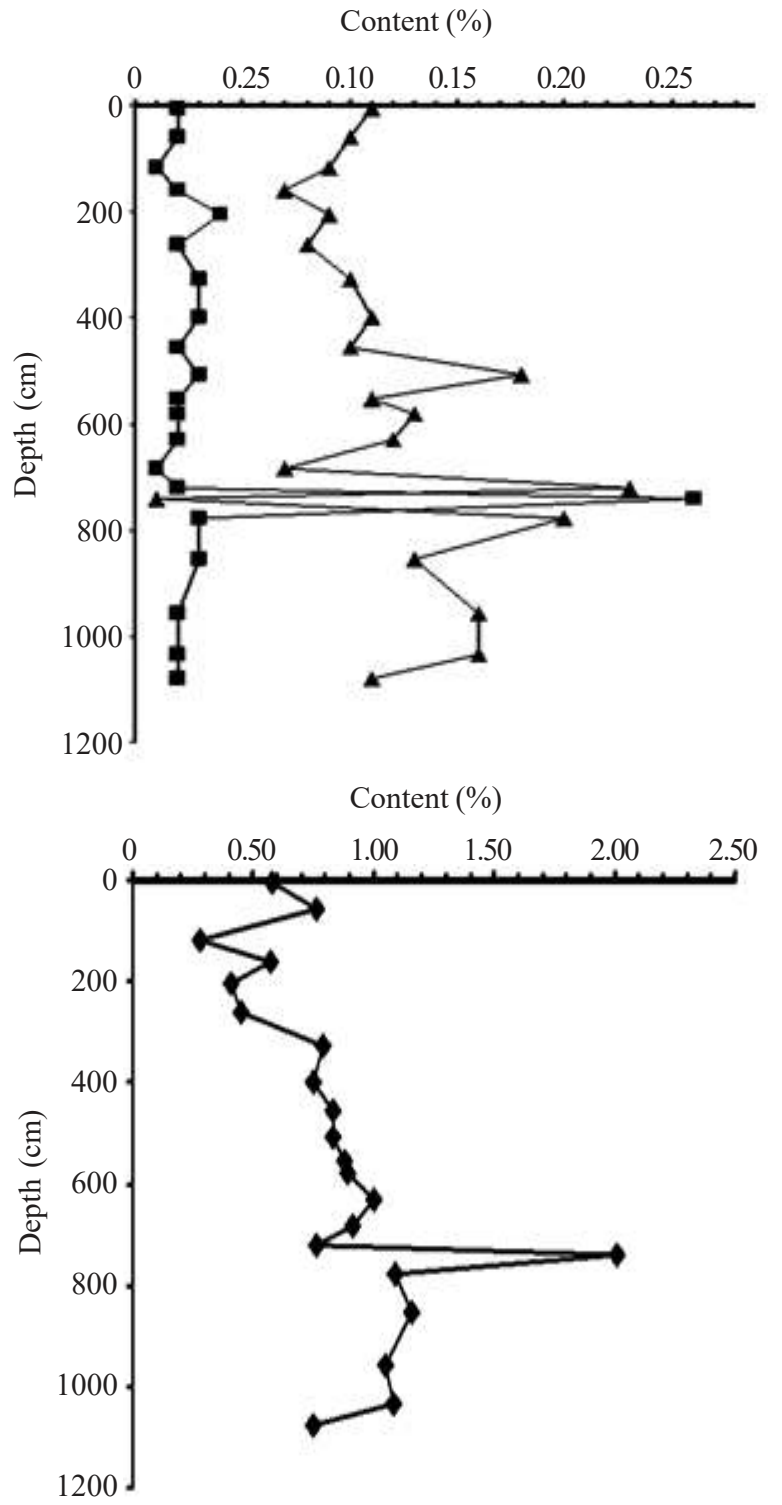

Figure 5. Vertical distribution of Alp and Fep (a) and organic carbon (b) in the soil profile. $\rightarrow$ : Fep, $\leftarrow$ : Alp, $\rightarrow$ : Organic C.

however the increase of pressure to a certain degree can suddenly damage the soil structure.

\section{Amorphous Materials in the Soil}

Table 3 shows that, in general, the low amounts of pyrophosphate extractable $\mathrm{Fe}, \mathrm{Al}$ and $\mathrm{Si}$ indicate an absence of organically bounded iron, aluminum and silica. An exception is shown in the layer 16 $(726-755 \mathrm{~cm})$ that has high amount of $\mathrm{Fe}_{\mathrm{p}}$, which is supported by the high amount of organic $\mathrm{C}$ content (Figure 5). On the other hand, the oxalic extractable $\mathrm{Al}$ and $\mathrm{Fe}$ are high, and it shows that $\mathrm{Al}$ and $\mathrm{Fe}$ are predominantly present as inorganically amorphous materials. The result of the current study is different from the development of volcanic soils in Costa Rica in which both oxalic extractable $\mathrm{Al}$ and $\mathrm{Si}$ were high as reported by Jongmans et al. (2000). Rasmussen 
Table 3. Selected soil chemical properties.

\begin{tabular}{|c|c|c|c|c|c|c|c|c|c|c|c|c|}
\hline \multirow[t]{2}{*}{ No } & \multirow{2}{*}{$\begin{array}{l}\text { Depth } \\
(\mathrm{cm})\end{array}$} & \multirow{2}{*}{$\begin{array}{c}\text { Org-C } \\
(\%)\end{array}$} & \multicolumn{3}{|c|}{ Oxalic (\%) } & \multicolumn{3}{|c|}{ Pyrophosphate (\%) } & \multirow{2}{*}{$\begin{array}{c}\text { P retention } \\
(\%)\end{array}$} & \multicolumn{3}{|c|}{$\mathrm{pH}$} \\
\hline & & & $\mathrm{Fe}$ & $\mathrm{Al}$ & $\mathrm{Si}$ & $\mathrm{Fe}$ & $\mathrm{Al}$ & $\mathrm{Si}$ & & $\overline{\mathrm{H}_{2} \mathrm{O}}$ & $\mathrm{KCl}$ & $\mathrm{NaF}$ \\
\hline 1 & $0-21$ & 0.58 & 1.16 & 2.34 & 0.10 & 0.02 & 0.11 & 0.01 & 66.8 & 6.1 & 5.3 & 10 \\
\hline 2 & $21-96$ & 0.76 & 1.16 & 3.02 & 0.12 & 0.02 & 0.01 & n.d. & 73.0 & 5.9 & 5.1 & 10 \\
\hline 3 & $96-138$ & 0.28 & 1.14 & 2.28 & 0.08 & 0.01 & 0.09 & n.d. & 59.4 & 6.0 & 5.2 & 10 \\
\hline 4 & $138-183$ & 0.57 & 1.25 & 2.29 & 0.09 & 0.02 & 0.07 & n.d. & 64.9 & 6.1 & 5.6 & 10 \\
\hline 5 & $183-229$ & 0.41 & 1.17 & 2.37 & 0.09 & 0.04 & 0.09 & 0.01 & 55.9 & 6.2 & 5.4 & 10 \\
\hline 6 & $229-295$ & 0.45 & 1.19 & 3.50 & 0.14 & 0.02 & 0.08 & 0.01 & 73.3 & 6.3 & 5.5 & 10 \\
\hline 7 & $295-359$ & 0.79 & 1.23 & 3.08 & 0.10 & 0.03 & 0.10 & 0.01 & 74.5 & 6.1 & 5.6 & 10 \\
\hline 8 & $359-441$ & 0.75 & 1.28 & 3.90 & 0.11 & 0.03 & 0.11 & 0.01 & 77.2 & 6.1 & 5.4 & 10 \\
\hline 9 & $441-468$ & 0.83 & 1.21 & 3.00 & 0.09 & 0.02 & 0.10 & n.d. & 59.5 & 6.1 & 5.4 & 10 \\
\hline 10 & $468-548$ & 0.83 & 1.19 & 3.64 & 0.08 & 0.03 & 0.18 & 0.01 & 64.4 & 6.1 & 5.0 & 10 \\
\hline 11 & $548-557$ & 0.88 & 1.19 & 3.42 & 0.08 & 0.02 & 0.11 & n.d. & 67.5 & 6.2 & 5.1 & 10 \\
\hline 12 & $557-605$ & 0.89 & 1.19 & 3.56 & 0.07 & 0.02 & 0.13 & n.d. & 60.5 & 6.2 & 5.1 & 10 \\
\hline 13 & $605-652$ & 1.00 & 1.20 & 4.16 & 0.04 & 0.02 & 0.12 & n.d. & 63.4 & 6.3 & 5.3 & 10 \\
\hline 14 & $652-714$ & 0.91 & 1.16 & 2.85 & 0.05 & 0.01 & 0.07 & n.d. & 42.8 & 6.1 & 5.3 & 10 \\
\hline 15 & $714-726$ & 0.76 & 1.17 & 1.63 & 0.07 & 0.02 & 0.23 & n.d. & 47.1 & 6.1 & 5.2 & 11 \\
\hline 16 & $726-755$ & 2.01 & 1.46 & 2.05 & 0.08 & 0.26 & 0.01 & 0.03 & 55.5 & 6.0 & 5.2 & 11 \\
\hline 17 & $755-798$ & 1.09 & 0.84 & 2.37 & 0.08 & 0.03 & 0.20 & n.d. & 57.9 & 6.2 & 5.4 & 11 \\
\hline 18 & $798-912$ & 1.16 & 1.33 & 2.50 & 0.05 & 0.03 & 0.13 & n.d. & 69.5 & 6.1 & 5.2 & 10 \\
\hline 19 & $912-1005$ & 1.05 & 1.21 & 2.51 & 0.06 & 0.02 & 0.16 & n.d. & 56.7 & 6.1 & 5.3 & 10 \\
\hline 20 & $1005-1063$ & 1.08 & 1.35 & 1.93 & 0.09 & 0.02 & 0.16 & n.d. & 48.9 & 6.4 & 5.6 & 9 \\
\hline 21 & $1063-1094$ & 0.75 & 0.49 & 2.48 & 0.06 & 0.02 & 0.11 & n.d. & 59.2 & 6.2 & 5.5 & 10 \\
\hline
\end{tabular}

n.d. : not detected.

et al. (2007) reported that the soil exhibited andic materials is characterized by soil bulk density $<0.9$ $\mathrm{g} \mathrm{cm}^{3}$ and $\mathrm{P}$-retention $>85 \%$; and the $\mathrm{P}$ retention is strongly correlated with $\mathrm{Al}+1 / 2 \mathrm{Fe}_{\mathrm{o}}$ value (Wilson et al. 2017). Recombination of $\mathrm{Al}$ and $\mathrm{Si}$ into allophane needs the $\mathrm{pH}$ range of 4.7-7.0. According to the results of the present study it is concluded that the predominant material in most soil layers is allophane.

Table 3 shows that $\mathrm{P}$ retention capacity is not proportionally related to the $\mathrm{pH}(\mathrm{NaF})$. This result is different from that reported by Michael et al. (2007) on the study of volcanic ash soils in southwestern Tanzania. Their results showed a good correlation between the phosphate retention capacity and $\mathrm{pH}(\mathrm{NaF})$. In the present study, the soil samples were collected from different layers of the deep profile, and every sample is different in parent material composition and age. In short, there are many factors that may influence the $\mathrm{P}$ retention capacity. Different result has been reported by Fiantis et al. (2011) on the study about volcanic ash material from Mt. Talang in Sumatra, which showed that the $\mathrm{P}$ retention is mainly controlled by active portion of $\mathrm{Al}$ and $\mathrm{Fe}$.

\section{Primary Minerals}

The results of the studied soil profile showed that the predominant primary minerals of the fine sand fraction were hypersthene, augite, green hornblende, labradorite, opaque minerals and rock fragments (data are not presented in the current study). Hypersthene and augite minerals are included in olivine minerals, which present as single chain silicate, and hornblende is included in amphibole minerals. Olivine minerals as the most weatherable mineral type were not found in the studied soil profile. According to the Bowen's reaction series, olivine, pyroxene and amphibole minerals are included in discontinuous reaction series and as series of increasing of mineral stability. Labradorite is included in plagioclase series of the results of continuous reaction series. Olivine and 


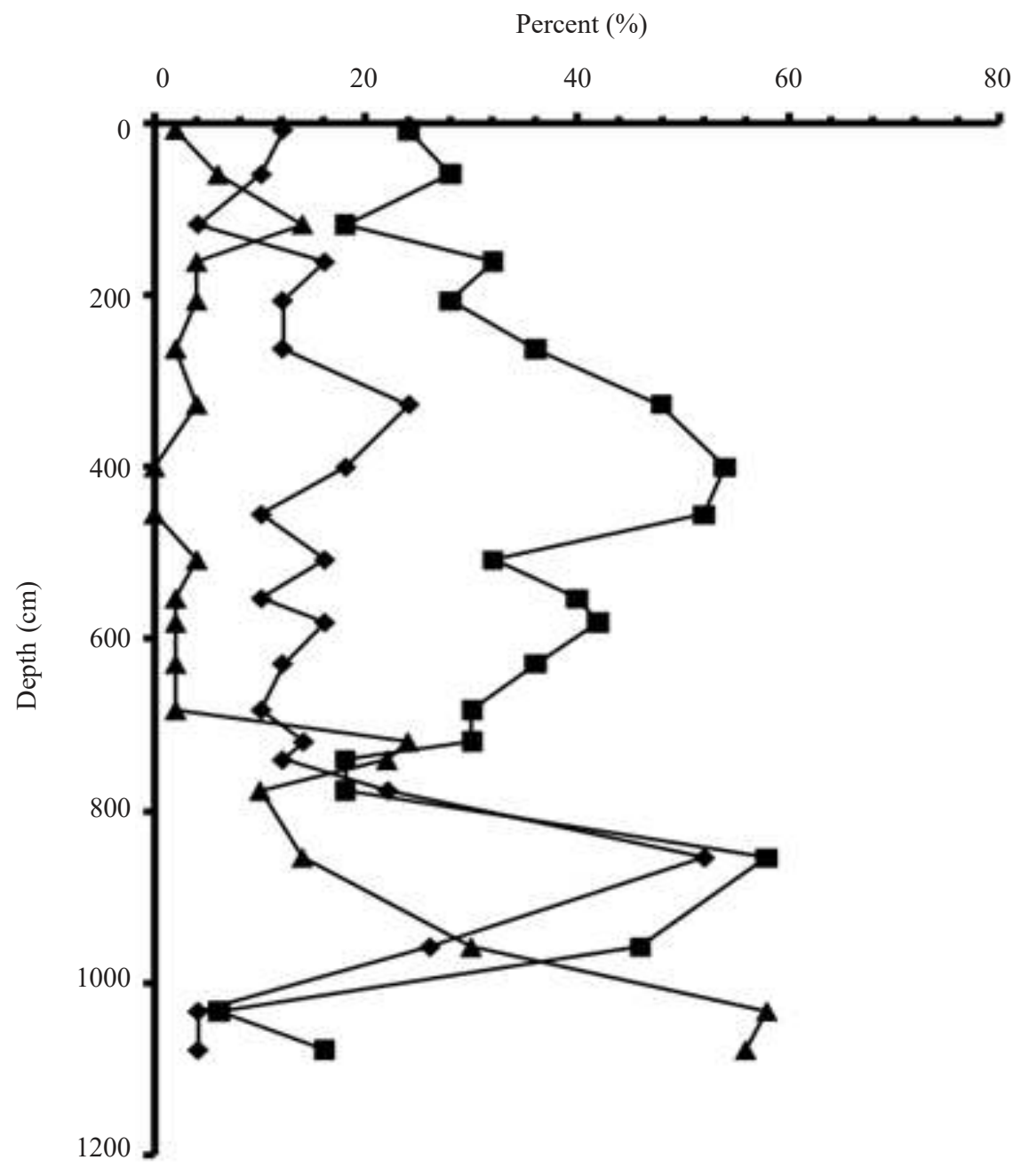

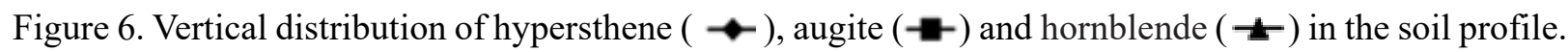

anorthite, the first formed minerals in the discontinuous and continuous reaction series, respectively, are the most susceptible in weathering (Wilson 2004). The soil genesis on andesitic lahar reported by Rasmussen et al. (2007) also showed that the optical analysis of the very fine sand fraction is confirmed by the presence of hornblende, andesine, and albite. Hypersthene, augite and labradorite as weatherable minerals may support the nutrient elements for soil fertility (Yatno et al. 2016).

Vertical distribution of the hypersthene, augite and hornblende minerals is shown in Figure 6. The result of the studied soil profile shows that the vertical distribution of the hypersthene and augite as single chain silicate minerals shows similar pattern. The vertical distribution of the hornblende mineral showed in the opposite to that of both hypersthene and augite minerals. Firstly, the contents of hypersthene and augite minerals are higher than that of hornblende mineral from the surface layer down to $777 \mathrm{~cm}$. Secondly, this feature is in opposite following the depth of 777 to $959 \mathrm{~cm}$. Thirdly, there is a tendency to change again that the contents of augite and hypersthene are lower than the hornblende. Vacca et al. (2003) reported the genesis of deep soil from repeated tephra depositions from the Roccamonfina Volcano, South Central Italy. Litholigic discontinuity in the pedogenesis was reported in subtropical mountainous areas, Sierra Sur de Oaxaca, Mexico, Revista Mexicana de Ciencias Geológicas (Krasilnikov et al. 2007). The present study shows several lithologic dsicontinuity from soil layers as from the differences in primary mineral composition in the fine sand fraction.

\section{CONCLUSIONS}

It is proposed that there was a cycle of magma crystallization processes from high temperature and low temperature. It was predicted that the interval of depositional processes was in a short period. The properties of physics, chemistry, and mineralogy are 
recorded in almost soil layers. The characteristics of each soil layer are mainly reflected by the volcanic materials that had been deposited, and there were no significant development for all soil layers. The predominant material of each layer was allophane, while a thin melanic material was found in the depth of 726 to $798 \mathrm{~cm}$.

\section{ACKNOWLEDGEMENTS}

We would like to thank the students of Department of Soil Science, Universitas Pembangunan Nasional Veteran Yogyakarta for helping us with field work, sampling, and laboratory analysis.

\section{REFERENCES}

Van Bemmelen RW. 1949. The Geology of Indonesia, vol 1A, General Geology of Indonesia and Adjacent Archiphelagoes, Government Printing Office, the Hague.

Chavarriaga MW, C Cerón Gabriel and C Correa Johan. 2017. Soil moisture retention and mass movement of volcanic soils from the" Sabinas" sector in Caldas, Colombia, Acta Agronómica 66: 588-597.

Day PR. 1965. Hydrometer method of particle size analysis, Methods of Soil Analysis. Agronomy 9: 562-566.

Díaz-Rodríguez JA and JC Santamarina. 1999. Thixotropy: the case of Mexico city soils, in XI Panamerican Conf on Soil Mech and Geotech Eng, pp. 441-448.

Egashira K, S Uchida and S Nakashima. 1997. Aluminumhumus complexes for accumulation of organic matter in black-colored soils under grass vegetation in Bolivia, Soil Sci Plant Nutr 43: 25-33.

Fiantis D, M Nelson, J Shamshuddin, TB Goh and E Van Ranst. 2011. Changes in the chemical and mineralogical properties of Mt. Talang volcanic ash in West Sumatra during the initial weathering phase. Commun Soil Sci Plant Anal 42: 569-585.

Gomez C, M Janin, F Lavigne, R Gertisser, S Charbonnier, P Lahitte, SR Hadmoko, M Fort, P Wassmer, V Degroot. 2010. Borobudur, a basin under volcanic influence: 361,000 years BP to present. $J$ Volcanol Geoth Res 196: 245-264.

Haamazaki T and EP Paningbatan Jr. 1988. Procedures for soil analysis', Technical Paper No. 1. University of The Philippines, Los Banos \& Tropical Agric. Res L. Center, Japan., p. 94.

Honna T, S Yamamoto S and K Matsui. 1988. A simple procedure to determine melanic index that is useful for differentiating melanic from fulvic Andisols. Pedologist 32: 69-78.

Hunziker M, O Arnalds and NJ Kuhn. 2019. Evaluating the carbon sequestration potential of volcanic soils in southern Iceland after birch afforestation. Soil 5: 223-238. doi: https://doi.org/10.5194/soil-5-223-2019.
Jahn R, HP Blume, VB Asio, O Spaargaren and P Schad. 2006. Guidelines for Soil Description. FAO.

Jongmans AG, L Denaix, F Van Oort and A Nieuwenhuyse. 2000. Induration of $C$ horizons by allophane and imogolite in Costa Rican volcanic soils. Soil Sci Soc Am J 54:254-262

Kleber M, C Mikutta and R Jahn. 2004. Andosols in Germany-pedogenesis and properties. Catena 56: 67-83.

Krasilnikov P, NEG Calderón and EF Romero. 2007. Pedogenesis and slope processes in subtropical mountain areas, Sierra Sur de Oaxaca, Mexico. Revista Mexicana de Ciencias Geológicas. Universidad Nacional Autónoma de México 24: 469-486.

McKeague JA. 1967. An evaluation of $0.1 \mathrm{M}$ pyrophosphate and pyrophosphate-dithionite in comparison with oxalate as extractants of the accumulation products in podzols and some other soils. Can J Soil Sci 47: 95-99.

Michael MSB, H Otsuka, S Araki and N Fujitake. 2007. Characterization of Volcanic ash Soils in SouthWestern tanzania: Morphology, physicochemical properties and Classification. Afr Study Monographs 34: 39-55.

Mulyaningsih S, S Hidayat, BA Rumato and G Saban. 2016. Identification of eruptional characteristics of Merbabu volcano based on stratigraphy and mineralogy of volcano. In: National Seminar on Science and Technology Applications (SNAST), 1p.

Murwanto H, Y Gunnell, S Suharsono, S Sutikno and F Lavigne. 2004. Borobudur monument (Java, Indonesia) stood by a natural lake: chronostratigraphic evidence and historical implications. The Holocene 14: 459-463.

Nanzyo M. 2002. Unique properties of volcanic ash soils. Global Environ Res-English Edition-6: 99-112.

Neall VE. 2009. Volcanic soils. Land use, land cover and Soil Sci 7: 23-45.

Rasmussen C, N Matsuyama, RA Dahlgren, RJ Southard and N Brauer. 2007. Soil genesis and mineral transformation across an environmental gradient on andesitic lahar. Soil Sci Soc Am J 71: 225-237.

Shoji S and T Takahashi. 2002. Environmental and agricultural significance of volcanic ash soils', Global Environ Res-English Edition, pp. 113-135.

Supriyo H, N Matsue and N Yoshinaga. 1992. Chemical and mineralogical properties of volcanic ash soils from Java. Soil Sci Plant Nutr 38: 443-457.

Takahashi T and RA Dahlgren. 2016. Nature, properties and function of aluminum-humus complexes in volcanic soils. Geoderma 263: 110-121.

Takahashi T and S Shoji. 2002. Distribution and classification of volcanic ash soils. Global Environ Res-English Edition, 6: 83-98.

Ugolini FC and RA Dahlgren. 2002. Soil development in volcanic ash. Global Environ Res-English Edition 6: 69-82.

Utami SNH. 2000. Physical and Chemical Properties of andisols from Mt. Merbabu and Mt Tangkuban Prahu. Soil Water J 1: 1-11. 
Vacca A, P Adamo, M Pigna and P Violante. 2003. Genesis of tephra-derived soils from the Roccamonfina volcano, south central Italy. Soil Sci Soc Am J 67: 198-207.

Van Bemmelan RW. 1949. The Geology of Indonesian and Adjacent Archipelago. The Hague: Government Printing Office.

Van Padang MN. 1951. Catalogue of the active volcanoes of the world including solfatara fields, part 1'. International Volcanological Association Naples.

Wilson MJ. 2004. Weathering of the primary rock-forming minerals: processes, products and rates. Clay Minerals 39: 233-266.

Wilson SG, JJ Lambert, M Nanzyo and RA Dahlgren. 2017. Soil genesis and mineralogy across a volcanic lithosequence, Geoderma 285: 301-312.
Yatno E, H Hikmatullah and M Syakir. 2016. Properties and management implications of soils developed from volcanic ash in North Sulawesi. $J$ Tanah dan Iklim 40: 1-10.

Zehetner F, WP Miller and LT West. 2003. Pedogenesis of volcanic ash soils in Andean Ecuador', Soil Sci Soc Am J67: 1797-1809.

Zhao L, M Satoh and K Inoue. 1997. Clay mineralogy and pedogenesis of volcanic ash soils influenced by tropospheric eolian bust in Changbaishan, Sanjiaolongwan, and Wudalianchi, Northeast China', Soil Sci Plant Nutr 43: 85-98. 